\title{
MENCARI PARADIGMA BARU MANAJEMEN MONETER DALAM SISTEM NILAI TUKAR FLEKSIBEL: Suatu Pemikiran untuk Penerapannya di Indonesia
}

\author{
Hartadi A. Sarwono, dan Perry Warjiyo *)
}

Kebijakan moneter Indonesia sampai saat ini pada dasamya masih menggunakan paradigma lama yang mengandalkan mekanisme transmisi kebijakan moneter melalui pengendalian jumlah uang beredar dalam mempengaruhi kegiatan ekonomi. Perekonomian Indonesia yang berubah cepat dan semakin terbuka, khususnya sejak langkah-langkah deregulasi di segala bidang sejak tahun delapan puluhan, ditengah-tengah lingkungan perekonomian dunia yang semakin terintegrasi, telah menyebabkan paradigma lama sistem pengendalian moneter dengan sasaran kuantitas (monetary aggregates targetting) tersebut menjadi semakin kurang relevan. Lebih dari itu, deregulasi dan gldbalisasi selama ini juga telah mendorong sektor keuangan berkenbang sangat cepat ke arah bekerjanya mekanisme pasar, timbulnya inovasi produk-produk keuangan baru dan gejala sekuritisasi, membaurnya operasi bank dengan lembaga-lembaga keuangan lainnya, serta terjadinya transnasionalisasi keuangan. Kesemuanya ini menyebabkan proses penciptaan uang lebih banyak lagi terjadi di luar kendali otoritas moneter sehingga pelaksanaan kebijakan moneter sering menjadi kurang efektif.

Di sisi lain, pasar keuangan dunia yang semakin terintegrasi dan ditunjang oleh semakin pesatnya perkembangan teknologi informasi dan komunikasi, telah menyebabkan perpindahan modal bergerak lebih cepat dan seringkali dalam jumlah yang besar mengikuti perkembangan ekonomi dan perubahan kebijakan suatu negara. Sebagai akibatnya, hampir tidak mungkin bagi otoritas moneter suatu negara untuk mengendalikan secara pasti perkembangan agregat-agregat moneter di dalam negeri. Sasaran agregat moneter yang diinginkan otoritas moneter sering tidak dapat dicapai karena arus modal intemasional yang keluar maupun masuk dalam jumlah yang besar dan dalam waktu yang singkat. Pengalaman kita selama ini menunjukkan semakin sulitnya mengarahkan agregat moneter sesuai dengan yang dikehendaki, tenutama dalam jangka pendek. Masalah ini terjadi karena uang beredar memang berada diluar kendali otoritas moneter, dimana perkembangannya lebih banyak dipenganuhi oleh kegiatan ekonomi dan bukan sebaliknya.

Tulisan ini ingin mengajukan proposisi mengenai sistem pengendalian moneter dengan penggunaan suku bunga dan nilai tukar sebagai intermediate target dalam mencapai sasaran akhir yakni inflasi. Mekanisme transmisi kebijakan moneter melalui suku bunga dan nilai tukar ini, atau disebut sebagai indikator kondisi moneter, diharapkan dapat memberikan signal yang lebih cepat kepada otoritas moneter dalam rangka menstabilisasikan harga.

\footnotetext{
*) Hartadi A. Sarwono : Deputi Kepala Urusan Riset Ekonomi dan Kebijakan Moneter, BI, Email: hartadi@bi.go.id Perry Warjiyo : Deputi Kepala Urusan Riset Ekonomi dan Kebijakan Moneter, BI, Email: perry_w@bi.go.id
}

Tulisan ini disarikan dari Makalah SESPIBI angkatan XXI 1996, Hartadi A. Sarwono, dan Makalah SESPIBI angkatan XXII 1997, Perry Warjiyo 
Pendahuluan

$\int$ ejak hampir satu dekade terakhir telah terjadi berbagai perubahan mendasar yang

() mempengaruhi pelaksanaan manajemen moneter di Indonesia. Pertama, reformasi yang dilakukan pada sektor keuangan dan perbankan telah mendorong tumbuh dan berkembangnya inovasi produk-produk keuangan baru. Dengan berkembangnya produk tabungan dan ATM, misalnya, sekarang sulit membedakan jenis rekening simpanan yang ditujukan untuk keperluan transaksi ekonomi dengan untuk maksud tabungan. Proses sekuritisasi telah semakin berkembang baik di sisi aktiva maupun sisi pasiva bank yang semakin memperluas berbagai media pembayaran ataupun media simpanan sebagaimana layaknya diperankan oleh uang. Kesemuanya ini menyebabkan definisi, cakupan, dan perilaku uang beredar telah pula mengalami perubahan.

Kedua, semakin berkembangnya sektor keuangan telah mendorong kecenderungan terjadinya proses pemisahan kegiatan (decoupling) antara sektor moneter dengan sektor riil. Kini uang tidak lagi dipandang sebagai alat pembayaran, akan tetapi juga sebagai komoditas yang diperdagangkan. Volume perputaran uang di sektor keuangan telah jauh melebihi kebutuhan pembiayaan di sektor riil. Proses disintemediasi semakin lama semakin menggejala. Akibatnya, hubungan antara uang beredar dengan berbagai variabel di sektor riil menjadi semakin kompleks dan sulit diprediksi. Fungsi permintaan uang yang selama ini digunakan sebagai salah satu acuan dalam manajemen moneter menjadi kurang stabil perilakunya.

Ketiga, sukses pembangunan ekonomi Indonesia telah mendorong derasnya aliran modal masuk dari luar negeri. Sebagian dari aliran dana tersebut berbentuk penanaman modal langsung ataupun pinjaman jangka menengah dan panjang. Akan tetapi sebagian lainnya berupa pinjaman dan investasi portofolio pada berbagai surat berharga berjangka pendek. Aliran modal luar negeri tersebut memang diperlukan untuk menutup kesenjangan tabungan dan investasi yang masih kita hadapi. Namun aliran dana tersebut, khususnya yang berjangka pendek, sangat rentan terhadap rumor dan spekulasi sehingga sewaktuwaktu dapat berbalik menjadi aliran dana ke luar negeri. Fenomena demikian menyebabkan pelaksanaan manajemen moneter menjadi lebih sulit. Pengalaman kita dengan gejolak nilai tukar Rupiah sejak pertengahan Juli 1997 yang lalu merupakan pelajaran berharga yang dapat kita tarik dalam hal ini.

Keempat, dan yang paling mendasar, sistim nilai tukar kita telah mengalami perubahan dari sistim mengambang terkendali dengan rentang intervensi menjadi sistim nilai tukar fleksibel. Gerakan nilai tukar kini tidak lagi dibatasi oleh rentang intervensi, akan tetapi lebih mencerminkan kekuatan permintaan dan penawaran di pasar valuta asing. Akibatnya, fluktuasi nilai tukar Rupiah menjadi semakin tinggi dan sulit diprediksi. Memang fleksibilitas nilai tukar dapat meringankan beban Bank Indonesia dalam melakukan sterilisasi atas dampak aliran modal masuk terhadap ekspansi uang beredar di dalam negeri. Akan tetapi fluktuasi nilai tukar yang tinggi itu sendiri menyebabkan pergeseran terms of trade yang dapat mempengaruhi permintaan aggregat, disamping dampak langsungnya terhadap laju inflasi karena imported inflation. Bagaimanapun juga fluktuasi nilai tukar tersebut harus diperhitungkan secara seksama dalam manajemen moneter di dalam negeri.

Keempat perubahan mendasar tersebut mengarah pada satu hal: bahwa manajemen moneter melalui transmisi uang beredar perlu dikaji ulang. Kita tidak bisa lagi terlalu 
mengandalkan pada pencapaian sasaran uang primer dan uang beredar (M1 dan M2) sebagai ukuran dari keberhasilan manajemen moneter. Hal ini mengingat telah terjadi perubahan mekanisme transmisi dari kebijakan moneter dalam mencapai sasaran akhir laju inflasi, laju pertumbuhan ekonomi, dan kemantapan neraca pembayaran. Transmisi kebijakan moneter melalui kuantitas seperti uang beredar dan kredit diyakini tidak sekuat dulu lagi. Mekanisme transmisi melalui harga seperti suku bunga dan nilai tukar diyakini lebih mendekati kenyataan di Indonesia dewasa ini dan di masa mendatang. Perubahan demikian mengharuskan kita untuk membangun rumusan baru mengenai mekanisme manajemen moneter di Indonesia.

Tulisan ini ingin mengemukakan beberapa pokok pikiran mengenai manajemen moneter dalam sistim nilai tukar fleksibel yang kiranya dapat diterapkan di Indonesia. Pada dasarnya ingin diajukan proposisi bahwa manajemen moneter melalui transmisi suku bunga dan nilai tukar diyakini lebih mendekati kenyataan dengan kondisi perekonomian dan sektor keuangan Indonesia yang telah semakin maju dan kompeks. Berangkat dari pemikiran demikian, dalam makalah ini dirumuskan sasaran akhir, sasaran antara dan variabel indikator, sasaran operational, dan instrumen dari kebijakan moneter yang kiranya dapat digunakan sebagai acuan dalam pelaksanaan manajemen moneter melalui transmisi suku bunga dan nilai tukar tersebut.

Agar alur pikir pemaparannya dapat lebih runtut, artikel ini dibagi ke dalam empat bab. Setelah bab pendahuluan ini, dalam bab Jalur Mekanisme Kebijakan Moneter Paradigma Lama versus Paradigma Baru akan diulas mengenai perbedaan antara paradigma lama dan paradigma baru mekanisme transmisi kebijakan moneter sebagai landasan bagi perumusan manajemen moneter. Selanjutnya dalam bab Merumuskan Kembali Sasaran Pengendalian Moneter Quantity vs. Price Targeting, akan dibahas pro dan kontra antara quantity dan price targetting. Bab Paradigma Baru Manajemen Moneter Indonesia Melalui Jalur Transmisi Suku Bunga dan Nilai Tukar secara rinci akan menjabarkan manajemen moneter melalui jalur transmisi suku bunga dan nilai tukar yang kiranya dapat diterapkan di Indonesia. Pemaparannya akan dimulai dengan gambaran umum mengenai kerangka dasar manajemen moneter dengan mempertimbangkan kenyataan-kenyataan baru dalam perekonomian kita. Setelah itu akan dibahas secara berurutan mengenai sasaran akhir, sasaran antara dan variabel indikator, sasaran operasional, serta instrumen kebijakan moneter yang dipandang dapat mendukung manajemen moneter melalui transmisi suku bunga dan nilai tukar tersebut. Bab terakhir merupakan kesimpulan dan saran dari makalah ini.

\section{Jalur Mekanisme Kebijakan Moneter Paradigma Lama versus Paradigma Baru}

Paradigma lama mekanisme transmisi sistem pengendalian moneter beranggapan bahwa otoritas moneter dapat secara langsung mengendalikan uang primer, kemudian dengan asumsi bahwa angka pengganda uang cukup stabil dan dapat diprakirakan dengan baik, maka uang beredar dapat pula dikendalikan. Selanjutnya, dengan asumsi bahwa income velocity relatif stabil, otoritas moneter melalui pengendalian uang beredar dapat mempengaruhi kegiatan ekonomi yang diinginkan sesuai dengan sasaran akhir kebijakan moneter yang ditetapkan.

Pengalaman kita dalam pengendalian moneter selama ini menuntut untuk mencari sudut pandang baru mekanisme transmisi tersebut, sehingga pemahaman kita dalam 
melaksanakan kebijakan moneter adalah dalam arti benar-benar "mengendalikan" suatu policy variable yang diharapkan dapat mempengaruhi pencapaian sasaran akhir. Ini merupakan suatu tugas yang berat karena menyangkut perubahan yang mendasar dari sistem pengendalian moneter baik ditinjau dari sisi teoritis dan empiris maupun pelaksanaan praktis operasionalnya. Kontroversi mengenai topik ini, baik dikalangan peneliti maupun di tingkat pengambil keputusan, masih sulit untuk direkonsiliasikan. Penelitian yang lebih mendalam secara teoritis dan empiris, diskusi dan tukar pikiran perlu terus dilanjutkan, sehingga perubahan mekanisme transmisi sistem pengendalian moneter yang memutarbalikkan paradigma lama lebih mantap lagi untuk dilaksanakan. ${ }^{1}$

Dalam berbagai literatur ekonomi-moneter, pada dasarnya terdapat empat jalur transmisi utama yang menunjukkan bagaimana kebijakan moneter dapat mempengaruhi perekonomian (Mishkin, 1995, Boediono, 1996, dan BIS 1995), yaitu : jalur suku bunga, jalur nilai tukar, jalur harga aset dan jalur kredit. ${ }^{2}$

Jalur suku bunga pada dasarnya merupakan pandangan Keynessian dimana suku bunga riil jangka panjang paling berpengaruh dalam perekonomian. Pengetatan moneter mengurangi uang beredar dan dalam jangka pendek akan mendorong naiknya suku bunga nominal jangka pendek. Apabila kebijakan ini dianggap credible, masyarakat akan mempunyai ekspektasi bahwa laju inflasi akan menurun di waktu mendatang sehingga expected inflation menurun atau suku bunga riil jangka panjang meningkat. Permintaan domestik baik untuk investasi maupun untuk konsumsi akan menurun karena biaya dana (cost of capital) yang lebih tinggi. Akhirnya laju pertumbuhan ekonomi cenderung lebih rendah.

Jalur nilai tukar berpandangan bahwa pergerakan nilai tukar paling berpengaruh bagi perekonomian khususnya perekonomian terbuka dengan sistem nilai tukar fleksibel. Pengetatan moneter akan mendorong suku bunga nominal dalam negeri meningkat. Jika suku bunga internasional tidak berubah maka interest rate differential meningkat, dan ini akan mendorong masuknya dana dari luar negeri. Nilai tukar akan cenderung apresiasi. Kegiatan ekspor akan menurun dan sebaliknya impor meningkat, sehingga transaksi berjalan dalam neraca pembayaran akan membaik. Akibatnya, permintaan aggregat akan menurun dan demikian pula laju pertumbuhan ekonomi dan laju inflasi.

Jalur harga aset merupakan pandangan Monetarist dimana pengaruh kebijakan moneter terjadi melalui pergeseran portfolio investasi yang dimiliki masyarakat. Kebijakan moneter akan mempengaruhi jumlah dana dalam portfolio para pelaku ekonomi (wealth effet) dan relokasi dari suatu jenis aset ke jenis aset lain dalam portfolio sesuai dengan expected retums and risks dari masing-masing bentuk aset. Dengan demikian, pengetatan moneter meningkatkan suku bunga yang mengakibatkan pelaku ekonomi lebih suka

1 Boediono (1996), dalam tulisannya "Merenungkan kembali mekanisme transmisi moneter di Indonesia", mengatakan bahwa untuk memulainya perlu dilakukan dengan menggali literatur muktahir, dan menarik pelajaran dari pengalaman kita maupun dari negara lain.

2 Untuk pembahasan yang lebih rinci, baca Mishkin (1995) dan Boediono (1996b). Sementara itu, BIS (1995) mengemukakan lima jalur transmisi kebijakan moneter yang sedikit berbeda, yaitu: (a) income/cash-flow channel, (b) wealth channel, (c) direct interest rate channel on consumption, (d) cost-of-capital channel, dan (e) exchange rate channel. 
memegang aset dalam bentuk obligasi atau deposito daripada saham. Minat untuk berinvestasi dalam kegiatan ekonomi riil menjadi berkurang sehingga laju pertumbuhan ekonomi menurun.

Jalur kredit berpendapat bahwa pengaruh kebijakan moneter terhadap kegiatan ekonomi terjadi melalui perubahan perilaku bank dalam menyalurkan kreditnya kepada nasabah. Pengetatan moneter akan menurunkan net worth pengusaha sehingga berakibat pada menurunnya nilai jaminan atas kredit yang diterimanya dari bank. Resiko yang dihadapi bank menjadi meningkat sehingga bank lebih berhati-hati dalam menyalurkan kredit (adverse selection). Menurunnya net worth juga akan mendorong nasabah untuk lebih berani mengusulkan proyek-proyek yang menjanjikan tingkat hasil yang tinggi akan tetapi dengan tingkat resiko kegagalan yang tinggi pula (moral hazard). Dan ini meningkatkan resiko kredit macet bank-bank. Dengan demikian dampak dari pengetatan moneter terhadap penurunan permintaan aggregat dan laju pertumbuhan ekonomi lebih disebabkan oleh menurunnya kredit yang disalurkan bank-bank baik karena faktor adkerse selection maupun untuk menghidari moral hazard nasabah.

Bagaimana transmisi kebijakan moneter di Indonesia selama ini? Telah dikemukan bahwa berbagai perubahan mendasar yang terjadi dalam perekonomian kita telah menyebabkan efektivitas kebijakan moneter yang selama ini ditempuh menjadi kurang efektif. Paradigma lama yang mengatakan bahwa otoritas moneter dapat mempengaruhi permintaan aggregat melalui pengendalian uang beredar (M1 dan M2) sebagai sasaran antara dan uang primer (M0) sebagai sasaran operasional perlu dikaji ulang (Boediono, 1994). Beberapa penelitian juga menunjukkan bahwa hubungan antara uang beredar, laju inflasi, dan laju pertumbuhan ekonomi menjadi semakin lemah sejak reformasi keuangan di Indonesia (Bond, et. al., 1994). ${ }^{3}$ Bahkan, yang terjadi adalah sebaliknya. Jumlah uang beredar baik M1 maupun M2 sangat dipengaruhi oleh perkembangan kegiatan ekonomi, sehingga seakan-akan merupakan arus balik yang sangat kuat mempengaruhi perkembangan uang primer. Dengan demikian, paradigma lama yang menyatakan bahwa jumlah atau kuantitas uang beredar dapat dikendalikan sepenuhnya oleh otoritas moneter menjadi tidak berlaku. Karena itu manajemen moneter melalui sasaran kuantitas nampaknya semakin kurang dapat dipertahankan lagi.

Semakin berkembangnya peran pasar dalam perekonomian nampaknya cenderung menyebabkan semakin pentingnya transmisi kebijakan moneter melalui "harga" uang atau suku bunga. Paradigma baru ini juga tidak terlepas dari semakin majunya sektor keuangan kita dengan berbagai karakteristik seperti majunya inovasi produk keuangan, proses sekuritisasi, maupun proses decoupling antara sektor moneter dengan sektor riil. Uang sekarang telah menjadi komoditas yang diperdagangkan. Karena itu "harga" uang menentukan perputaran uang, alokasi uang dari berbagai jenis investasi, serta kegiatan perekonomian secara keseluruhan.

Suku bunga merupakan "harga" uang yang terpenting dalam perekonomian sehingga merupakan jalur transmisi kebijakan moneter yang diyakini lebih mendekati kenyataan

3 Lihat misalnya Bond, et. al..(1994) yang meneliti hubungan antara M1 dan M2 dengan laju inflasi dan laju pertumbuhan ekonomi dari kuartal pertama tahun 1985 hingga 1994. Hasilnya menunjukkan hubungannya sangat lemah sehingga disimpulkan bahwa uang beredar kurang tepat dipergunakan sebagai sasaran antara. 
(Bond, 1994). . Hal ini dikarenakan suku bunga menentukan keputusan mengenai alternatif investasi di masyarakat. Kenaikan suku bunga, misalnya, akan menyebabkan investasi dan konsumsi di sektor riil menjadi kurang menarik. Masyarakat akan lebih tertarik untuk menanamkan dananya pada tabungan, deposito maupun obligasi. Perpindahan dana dari sektor riil ke sektor moneter menyebabkan permintan aggregat dan laju pertumbuhan ekonomi menurun. Mekanisme kebijakan moneter melalui jalur transmisi suku bunga pernah diajukan oleh Sarwono (1996).

Akan tetapi dalam ekonomi terbuka dengan sistim nilai tukar fleksibel "harga" uang yang lain yaitu nilai tukar Rupiah juga menjadi semakin penting. Telah dikemukakan di atas bahwa kebijakan moneter mempengaruhi nilai tukar dan sistim nilai tukar fleksibel mendorong fluktuasi nilai tukar yang lebih besar. Gerakan nilai tukar mengubah harga relatif sehingga mempengaruhi perkembangan ekspor dan impor. Selanjutnya gerakan nilai tukar tersebut akan mempengaruhi permintaan aggregat, laju pertumbuhan ekonomi, dan laju inflasi. Di berbagai negara yang menganut sistim nilai tukar fleksibel menunjukkan bahwa jalur nilai tukar menjadi semakin penting dalam mentransmisikan kebijakan moneter (BIS, 1995). ${ }^{5}$

Paradigma baru yang lebih meyakini jalur suku bunga dan jalur nilai tukar sebagai jalur utama transmisi kebijakan moneter bukan berarti memandang kurang pentingnya jalur kredit. Kecenderungan adverse selection dan moral hazard merupakan fenomena yang sering dijumpai dalam bisnis perbankan. Akan tetapi kenyataan ini pada dasarnya merupakan dampak lanjutan dari perubahan suku bunga dan nilai tukar tersebut. Demikian pula mengenai jalur harga asset. Pada dasarnya ada tiga harga asset dalam perekonomian, yaitu: suku bunga pada pasar uang Rupiah, nilai tukar pada pasar valuta asing, dan harga saham pada pasar modal. Keseimbangan pada ketiga pasar ini dapat direfleksikan pada dua dari tiga harga asset tersebut. ${ }^{6}$ Dengan demikian gerakan suku bunga dan nilai tukar secara otomatis juga merefleksikan gerakan harga saham.

Dasar pemikiran di atas mengarah pada suatu pandangan bahwa gerakan suku bunga dan nilai tukar merupakan variabel penting dalam mentransmisikan pengaruh kebijakan moneter terhadap kegiatan perekonomian. Karena itu manajemen moneter di Indonesia hendaknya dibangun atas mekanisme transmisi suku bunga dan nilai tukar yang diyakini lebih mendekati kenyataan daripada transmisi melalui uang beredar yang selama ini dipergunakan sebagai dasar pijakan.

4 Bond (1994) menunjukkan secara empiris bahwa hubungan antara suku bunga dengan laju inflasi jauh lebih kuat dibandingkan dengan hubungan antara uang beredar dengan laju inflasi, sehingga diusulkan agar suku bunga dipergunakan sebagai sasaran kebijakan moneter.

5 Hasil survei oleh BIS (1995) terhadap mekanisme transmisi kebijakan moneter di berbagai negara maju menunjukkan kecenderungan demikian, disamping jalur suku bunga sebagai indikator cost of capital dalam melakukan kegiatan investasi.

6 Ingat bahwa dalam suatu Walrasian system apabila terdapat sebanyak (n) pasar dalam perekonomian, maka keseimbangan dalam perekonomian dapat diwujudkan apabila terjadi keseimbangan pada (n-1) pasar. 


\section{Merumuskan Kembali Sasaran Pengendalian Moneter} Quantity vs. Price Targeting

Di dalam literatur ekonomi-moneter, yang mendasari dipilihnya kuantitas uang primer sebagai instrumen pengendalian moneter adalah bahwa jumlah uang primer berada pada kendali otoritas moneter. Dengan asumsi money multipliers stabil dan dapat diprakirakan dengan baik, perubahan uang primer akan mempengaruhi komposisi neraca bank-bank (portofolio bank) yang pada gilirannya mempengaruhi kegiatan ekonomi. Dalam hal ini, perubahan komposisi neraca bank terjadi karena perubahan uang primer (dimana salah satu komponennya adalah bank reserve), akan diakomodir oleh bank dengan mengubah komposisi asetnya -utamanya kredit- atas inisiatif bank itu sendiri. Dalam grafik quantity vs price dari uang beredar, money supply menjadi vertikal yang perubahannya dikendalikan oleh bank sentral, sedangkan sukubunga hanya mengikuti kearah keseimbangan yang terjadi; sudut pandang teori ini disebut verticalist?

Sudut pandang verticalist dirasakan kurang relevan dengan berkembangnya sistem keuangan (financial system) yang semakin maju dan efisien yang ditandai dengan adanya transnasionalisasi keuangan, inovasi produk-produk baru, gejala sekuritisasi, dan membaurnya operasi bank-bank komersial dengan lembaga keuangan lainnya. Terintegrasinya pasar keuangan dunia telah pula menyebabkan operasi lembaga keuangan tidak lagi terbatas pada suatu negara atau wilayah (borderless world). Uang dan kredit mengalir dari satu tempat ke tempat lainnya mengikuti perputaran roda kegiatan ekonomi. Implisit dalam perkembangan ini, kegiatan ekonomi mencari sumber pembiayaannya sendiri yang tidak lagi terbatas pada suatu negara ataupun suatu lembaga keuangan tertentu. ${ }^{8}$ Perkembangan teknologi informasi dan komunikasi juga telah mendorong terciptanya sistem pembayaran (payment system) dengan instrumen yang lebih modern seperti credit card, debit card, automatic teller madhine, electronic funds transfer, dan point of sale. Demikian pula, bermunculan inovasi-inovasi baru dalam berbagai bentuk turunan dari financial assets (derivatives) seperti swap, qption, financial futures.

Perkembangan sistem keuangan dan sistem pembayaran dewasa ini mengaburkan pengertian uang yang kini lebih dari sekedar uang kertas dan logam atau fiat money melainkan telah meluas menjadi credit money. Sebagai akibatnya, aktivitas penciptaan uang oleh sistem keuangan meluas dan berlipat ganda melebihi penciptaan uang oleh bank sentral. Jumlah atau kuantitas uang beredar tidak lagi dapat dikendalikan secara pasti oleh bank sentral, karena semakin banyak ditentukan dari sisi permintaan (demand determined). Nasabah bank dan lembaga keuangan lainnya baik secara individual maupun secara agregat menentukan rencana kegiatan ekonominya yang tercermin dari kebutuhan pembiayaannya, yang selanjutnya diterjemahkan kedalam permintaan akan uang. Perkembangan ini menyebabkan berubahnya trend dan kestabilan dari money multipliers dan velocity of money; padahal, pengendalian kuantitas uang beredar sangat tergantung dari kestabilan kedua parameter ini.

7 Lihat, Basil J. Moore (1988) dalam bukunya "Horizontalists and Verticalists : the Macroeconomics of Credit Money".

8 Literatur menarik mengenai phenomena deregulasi dan globalisasi pasar keuangan dunia dapat dilihat pada Kenichi Ohmae "The End of The Nation State", dan Yasuke Kashiwagi "The Emeregence of Global Finance". 
Dengan demikian, sudut pandang lama yang beranggapan bahwa permintaan agregat dan kegiatan perekonomian ditentukan oleh pengendalian uang beredar (verticalist) secara perlahan namun pasti akan berubah haluan sejalan dengan perkembangan sistem keuangan (financial system) dan sistem pembayaran (payment system) yang bekerja lebih efisien didasarkan pada mekanisme pasar. Mekanisme transmisi yang terjadi adalah sebaliknya; uang beredar dipengaruhi oleh kegiatan ekonomi yang dibiayai oleh kredit bank dan lembaga keuangan lainnya pada suatu harga (sukubunga) tertentu dan suatu persyaratan tertentu. Harga dari sumber dana yang ditentukan oleh sistem keuangan pada dasarnya dapat dipengaruhi oleh otoritas moneter sebagai supplier dari ujung akhir sumber dana yaitu uang primer. Bank sentral dapat membuat mahal harga uang di pasar uang antarbank yang kemudian ditransmisikan keseluruh spectrum suku bunga jangka menengah-panjang.

Nasabah bank akan memperhitungkan kembali proyeknya; keputusan apakah ia akan meneruskan atau menunda proyeknya adalah sepenuhnya ditangan nasabah. Sudut pandang baru ini beranggapan bahwa sukubunga (price) dapat dikendalikan oleh otoritas moneter, dan uang beredar (quantity) akan berubah mengikuti keseimbangannya. Dalam grafik quantity vs price dari uang beredar, kurva money supply menjadi horisontal pada tingkat sukubunga tertentu yang diinginkan oleh bank sentral, sedangkan kuantitas uang beredar bergerak kearah kesimbangan permintaan dengan penawaran. Oleh karena itu, sudut pandang baru ini disebut horizontalist. Bank sentral tidak mempunyai pilihan lain kecuali mempengaruhi sukubunga jangka pendek pada suatu tingkat dimana kuantitas uang beredar yang terjadi akan ditentukan oleh permintaan sistem keuangan. Sistem keuangan berada pada posisi sebagai supplier dari uang beredar sesuai dengan jumlah kredit yang diperlukan untuk membiayai kegiatan ekonomi, sehingga dalam sudut pandang baru ini uang beredar pada dasarnya adalah credit driven.

Dalam literatur ekonomi-moneter classic, berbeda dengan padangan Currency School yang dipelopori oleh Locke dan Hume, Banking School yang dipelopori oleh Tooke dan John Stuart Mill, menyatakan bahwa dalam perekonomian modern dengan sistem keuangan yang telah maju dan efisien, uang lebih dari sekedar uang kertas dan logam (fiat money) karena uang dapat tercipta dengan aktivitas pemberian kredit oleh bank dan lembaga keuangan lainnya. Kuantitas uang beredar dalam arti credit money bereaksi secara pasif sesuai dengan perubahan permintaan akan kredit (credit driven). Perbedaan kedua pendapat tersebut dewasa ini telah berkurang, para akademisi dan praktisi bank sentral menyadari bahwa perkembangan sistem keuangan dan sistem pembayaran tidak lagi membatasi uang hanya sebagai uang kertas dan logam tetapi telah berkembang menjadi credit money yang dapat tercipta oleh adanya permintaan. ${ }^{9}$

Sementara itu, perkembangan yang telah terlihat lebih nyata sebagai akibat dari deregulasi dan globalisasi di sektor keuangan adalah semakin likuidnya tabungan dan deposito karena ada yang dapat ditarik sewaktu-waktu dan perhitungan bunganya dapat dilakukan atas dasar harian. Giro bank sebagian telah pula diberikan jasa giro untuk lebih menarik nasabah karena semakin tingginya kompetisi antarbank. Perkembangan ini mengakibatkan substitusi diantara komponen uang beredar (monetary assets) menjadi semakin dekat (close substitutes). Penubahan elastisitas substitusi (elasticity of substitution)

9 Studi literatur mengenai teori pengendalian moneter dapat dilihat misalnya pada: Harris (1981) \& Moore (1988). 
diantara komponen uang beredar ini, antara lain mengakibatkan tidak stabilnya money multipliers dan perlunya dilakukan redefinisi dari uang dalam arti sempit (M1) maupun dalam arti yang lebih luas lagi (M2 dan M3) karena komponen-komponennya telah menjadi semakin dekat hubungannya. Demikian pula, persamaan permintaan uang (demand for money) perlu dilakukan reestimasi untuk menjawab pertanyaan apakah ketidakstabilan persamaan tersebut diakibatkan oleh definisi uangnya yang salah ataukah hubungan antara uang beredar dengan output dan inflasi memang telah terputus. Kita ketahui bahwa kestabilan persamaan permintaan uang ini merupakan prasyarat bagi efektivitas pengendalian kuantitas uang beredar.

Dengan demikian, dapat kita simpulkan bahwa perkembangan yang cepat di sektor keuangan, telah mengurangi kemampuan bank sentral dalam mengendalikan besaran atau kuantitas uang beredar. Dengan semakin meluasnya transnasionalisasi keuangan, inovasi produk dan proses keuangan, serta gejala sekuritisasi aset, maka penciptaan uang beredar semakin banyak terjadi di luar otoritas moneter. Perkembangan ini menyebabkan kestabilan dari persamaan permintaan uang, multipliers, dan velocity yang menjadi terganggu, padahal kesemuanya ini merupakan prasyarat bagi efektivitas pengendalian jumlah uang beredar. Sementara itu, perkembangan pembiayaan ekonomi yang semakin meluas yang tidak saja melibatkan bank dan lembaga keuangan lainnya tetapi juga melibatkan cara pembiayaan yang lebih luas dari instrumen konvensional (kredit), telah menekankan pentingnya mekanisme transmisi pengendalian moneter melalui sukubunga.

Paradigma Baru Manajemen Moneter Indonesia

Melalui Jalur Transmisi Suku Bunga dan Nilai Tukar.

Kebijakan Moneter Dalam Sistem Nilai Tukar Fleksibel

Pertanyaan pertama yang perlu kita jawab dalam memahami kebijakan moneter dalam sistim nilai tukar fleksibel adalah bagaimana sistim nilai tukar tersebut akan dilaksanakan di Indonesia. Kesepakatan umum dewasa ini mengarah pada suatu pendapat bahwa gerakan nilai tukar akan dibiarkan sesuai kekuatan pasar, namun intervensi Bank Indonesia tetap dimungkinkan apabila kondisi memang memerlukan. Pernyataan inilah yang perlu mendapat penjelasan lebih lanjut. Bahwa intervensi memang diperlukan dapat dimengerti karena di negara manapun yang menganut sistim nilai tukar fleksibel pernah dan perlu melakukan intervensi. ${ }^{10}$ Namun intervensi tersebut biasanya tidak diarahkan untuk mencapai suatu "level" tertentu, apalagi "level" yang dianggap sebagai tingkat nilai tukar ekuilibrium, kecuali apabila memang diyakini telah terjadi exchange rate misalignment (Edwards, 1994)."11 Anggapan dasar ditempuhnya sistim nilai tukar fleksibel

10 Kesepakatan negara-negara G-7 untuk secara bersama-sama melakukan intervensi untuk mengatasi semakin menguatnya dolar Amerika Serikat yang kemudian dikenal dengan Plaza Accord tahun 1992 merupakan contoh populer dalam kasus ini. Dalam pertemuan negara-negara G-7 memang pergerakan nilai tukar merupakan salah satu agenda yang sering dibicarakan.

11 Edwards (1994) berpendapat bahwa intervensi diperlukan apabila misalignment tersebut disebabkan oleh kesalahan kebijakan ekonomi makro (macroeconomic induced misalignment) atau oleh perubahan struktural dalam ekonomi (structural induced misalignment). 
adalah keyakinan bahwa pasar telah berkembang secara efisien sehingga mampu menentukan sendiri tingkat ekuilibrium nilai tukar tersebut. Bahkan apabila terjadi suatu kejutanpun, efisiensi pasar dapat secara cepat menyesuaikan tingkat ekuilibrium tersebut ke tingkat yang baru. Dengan demikian, intervensi Bank Indonesia hanya diperlukan apabila terdapat gejala ketidakrasionalan perilaku pasar sehingga menghalangi bekerjanya pasar tersebut secara efisien. Menurunnya secara drastis kepercayaan pelaku pasar dan masyarakat luas terhadap gerakan nilai tukar yang mengarah pada terjadinya kepanikan yang meluas merupakan kondisi pokok diperlukannya intervensi Bank Indonesia di pasar.

Implikasi dari ditempuhnya sistim nilai tukar fleksibel tersebut cukup mendasar bagi perekonomian Indonesia. ${ }^{12}$ Fluktuasi dan karenanya ketidakpastian mengenai gerakan nilai tukar Rupiah jelas akan menjadi tinggi. Peranan ekspektasi pelaku pasar dan masyarakat akan menjadi lebih penting dalam mempengaruhi gerakan nilai tukar (Dornbusch, 1976). ${ }^{13}$ Secara langsung fluktuasi nilai tukar tersebut akan mempengaruhi tingkat harga di dalam negeri karena banyaknya barang-barang impor (imported inflation). Harga relatif (real effective exchange rates) juga akan semakin berfluktuasi dan berpengaruh terhadap kinerja ekspor dan impor, dan karenanya mempunyai dampak yang semakin perlu diperhitungkan terhadap permintaan aggregat. Laju pertumbuhan ekonomi juga dapat terpengaruh. Pendeknya fluktuasi nilai tukar yang lebih tinggi akan mempengaruhi sasaran-sasaaran laju inflasi, laju pertumbuhan dan keseimbangan neraca pembayaran yang hendak dicapai oleh kebijakan ekonomi makro.

Bagaimana kebijakan moneter dapat mempengaruhi perkembangan berbagai variabel ekonomi? Yang jelas, dalam sistim nilai tukar fleksibel Bank Indonesia dapat lebih bebas dalam melaksanakan kebijakan moneter dalam negeri karena tidak dituntut untuk melakukan sterilisasi atas dampak aliran dana masuk terhadap perkembangan uang beredar untuk mempertahankan suatu tingkat atau kisaran nilai tukar tertentu. Dengan demikian, pengendalian moneter dapat lebih difokuskan pada pencapaian sasaran-sasaran di dalam negeri. Dalam hal melakukan suatu kontraksi, misalnya, ketatnya likuiditas akan mendorong meningkatnya suku bunga di dalam negeri. Aliran dana masuk dari luar negeri akan meningkat dan menyebabkan nilai tukar Rupiah cenderung apresiasi. Permintaan domestik baik konsumsi maupun investasi akan menurun karena tingginya suku bunga dan menurunnya harga relatif. Laju pertumbuhan ekonomi akan cenderung lebih rendah. Laju inflasi juga akan menurun baik karena apresiasi nilai tukar maupun karena menurunnya permintaan domestik. Secara umum dapat dikatakan bahwa dalam sistim nilai tukar fleksibel kebijakan moneter dapat lebih efektif dalam mempengaruhi gerakan ekonomi dalam jangka pendek (Guitan, 1994a; Flood dan Musa, 1994). ${ }^{14}$

12 Model Mundell-Flemming merupakan acuan pokok dalam membahas hubungan berbagai variabel ekonomi dalam ekonomi terbuka dengan sistim nilai tukar fleksibel. Dornbusch (1980) membahas lebih mendalam model ini dan perluasannya dengan memasukkan faktor ekspektasi, rigiditas harga dalam negeri, serta kebijakan stabilisasi yang diperlukan dalam masalah ini.

13 Bahkan ekspektasi tersebut dapat menyebabkan fluktuasi nilai tukar menjadi overshooting, dalam arti bahwa penyesuaian nilai tukar dalam jangka pendek atas terjadinya suatu kejutan ekonomi tertentu jauh lebih besar dari yang dapat diperkirakan dalam jangka panjang. Baca Dornbusch (1976) untuk mendalami permasalahan ini.

14 Ingat bahwa dalam jangka panjang kebijakan moneter hanya berpengaruh terhadap laju inflasi. Dengan demikian, penggunaan kebijakan moneter yang lebih aktif (dengan discretion daripada rule) hanya dimaksudkan untuk mempengaruhi gerakan ekonomi dalam jangka pendek. Tulisan Guitian (1994a) serta Flood dan Mussa (1994) merupakan referensi yang baik dalam memahami berbagai permasalahan dalam manajemen moneter. 
Akan tetapi independensi tersebut menuntut disiplin yang lebih tinggi dalam pelaksanaan kebijakan moneter. Hal ini mengingat kejutan-kejutan yang terjadi pada pasar uang dapat mempunyai dampak yang merugikan bagi perekonomian. Ekspansi moneter yang berlebihan, misalnya, akan mendorong suku bunga lebih rendah, menurunnya aliran dana masuk atau bahkan terjadinya aliran dana ke luar negeri, depresiasi nilai tukar, serta meningkatnya permintaan domestik, laju pertumbuhan ekonomi dan laju inflasi (Guitan, 1994b). ${ }^{15}$ Yang perlu dikhawatirkan adalah ketidakdisiplinan kebijakan moneter tersebut dalam jangka pendek dapat mendorong fluktuasi nilai tukar Rupiah yang lebih besar karena kecenderungan overshooting yang disebabkan oleh rigiditas harga-harga di dalam negeri (Dornbusch, 1976).

\section{Kerangka Dasar Manajemen Moneter}

Kerangka dasar manajemen moneter yang diterapkan di berbagai bank sentral pada umumya tidak banyak berbeda. Di satu sisi, bank sentral ingin mencapai sasaran-sasaran akhir yang menjadi tugas pokoknya seperti laju inflasi, laju pertumbuhan ekonomi, dan keseimbangan neraca pembayaran. Namun di sisi yang lain, bank sentral hanya mampu mempengaruhi beberapa instrumen kebijakan yang secara langsung di bawah pengendaliannya. Karena itu diperlukan sasaran operasional sebagai sasaran segera yang hendak dicapai dari penggunaan instrumen tersebut dan, dengan suatu mekanisme tertentu yang diasumsikan, dapat mempengaruhi sasaran antara. Pada dasarnya pencapaian sasaran antara ini diharapkan dapat mempengaruhi pencapaian sasaran akhir yang diinginkan. Alur mekanisme manajemen moneter demikian dapat digambarkan sebagai: instrumen kebijakan moneter $\rightarrow$ sasaran operasional $\rightarrow$ sasaran antara $\rightarrow$ sasaran akhir (Friedman, 1975). ${ }^{16}$

Perbedaan pokoknya terdapat pada sedikitnya dua hal. Pertama, pemilihan variabel ekonomi yang dipergunakan sebagai sasaran operasional dan sasaran antara perlu disesuaikan dengan keyakinan perumus kebijakan atas mekanisme transmisi kebijakan moneter dan kondisi perekonomian yang diantisipasikan. Dengan demikian, apabila transmisi melalui suku bunga dan nilai tukar diyakini lebih mendekati kenyataan dalam perekonomian Indonesia, maka manajemen moneter akan menggunakan suku bunga dan nilai tukar sebagai sasaran operasional dan sasaran antara.

Kedua, semakin maju dan kompleksnya perekonomian dan sektor keuangan kita menyebabkan hubungan antara berbagai variabel dalam perekonomian menjadi semakin kompleks dan sulit diprediksi. Kecenderungan ini mendorong perumus kebijakan tidak boleh secara kaku dan dogmatis hanya meyakini suatu mekanisme kebijakan moneter tertentu. Perumus kebijakan harus mampu menggali dan mengintepretasikan berbagai data dan informasi untuk semakin mendalami perkembangan perekonomian pada waktu

15 Guitan (1994b) memberikan referensi yang bagus dalam mereview kelebihan dan kekurangan sistim nilai tukar tetap dan fleksibel. Antara lain dikatakan bahwa sistim fleksibel lebih baik apabila sebagian besar kejutan dalam ekonomi berasal dari sektor eksternal dan sektor riil, sementara sistim kurs tetap lebih unggul untuk menghadapi kejutan nominal domestik.

16 Kerangka dasar manajemen moneter seperti ini telah banyak dibahas dalam literatur ekonomi. Baca misalnya Friedman (1975). 
sekarang dan arahnya ke depan. Meskipun suatu kerangka dasar manajemen moneter telah diletakkan, peran dari variabel-variabel indikator menjadi semakin penting. Dengan kata lain, pendekatan pragmatis dan eklektik dalam manajemen moneter nampaknya merupakan alternatif yang banyak ditempuh di berbagai negara (Madigan, 1994; Sawamoto dan Ichikawa, 1994). ${ }^{17}$ Pendekatan demikian kiranya dapat pula dilakukan di Indonesia seperti pernah dinyatakan oleh Gubernur Bank Indonesia (Djiwandono, 1994) .

Dengan pemikiran di atas, maka manajemen moneter di Indonesia dapat dilakukan dengan mekanisme sebagaimana digambarkan pada lampiran. Berdasarkan pertimbanganpertimbangan yang akan dikemukakan secara rinci pada bagian-bagian di bab ini, dalam skema tersebut digambarkan bahwa sasaran akhir manajemen moneter adalah laju inflasi dan laju pertumbuhan ekonomi. Untuk mencapai sasaran akhir ini, Bank Indonesia akan memonitor secara seksama Indikator Kebijakan Moneter (IKM) yang mencerminkan pengaruh suku bunga deposito atau kredit dan real effective exchange rate (REFR) terhadap tekanan permintaan aggregat. Bank Indonesia juga perlu memonitor berbagai variabel indikator lainnya, khususnya prompt indicators dan leading indicators, untuk lebih memahami perkembangan perekonomian terkini dan arahnya di masa mendatang. Selanjutnya gerakan IKM tersebut akan dipengaruhi dengan perkembangan suku bunga jangka pendek seperti suku bunga PUAB, suku bunga SBI atau tingkat diskonto SBPU sebagai sasaran operasional. Dalam pelaksanaannya, manajemen moneter dengan mekanisme di atas akan ditempuh dengan instrumen sebagaimana yang telah dipergunakan selama ini yaitu Operasi Pasar Terbuka (OPT), reserve requirement, fasilitas diskonto, dan moral suasion.

\section{Sasaran Akhir}

Selama ini manajemen moneter di Indonesia diarahkan untuk mencapai sasaran akhir kestabilan ekonomi makro, yaitu laju inflasi yang cukup rendah, laju pertumbuhan ekonomi yang cukup tinggi, dan kemantapan neraca pembayaran. Berbagai perubahan mendasar yang dikemukan pada bab pendahuluan, khususnya sistim nilai tukar fleksibel, mengharuskan kita untuk memikirkan kembali tentang bagaimana kebijakan moneter dapat diarahkan untuk mencapai sasaran-sasaran tersebut. Yang jelas, dalam sistim yang baru kebijakan nilai tukar tidak lagi dapat diharapkan untuk mencapai sasaran peningkatan ekspor dan karenanya kemantapan neraca pembayaran. Seperti telah dijelaskan, dalam sistim nilai tukar fleksibel gerakan nilai tukar akan berfluktuasi sesuai dengan kekuatan pasar sehingga tidak lagi dapat diarahkan untuk mencapai suatu sasaran tingkat depresiasi tertentu untuk mendorong ekspor.

Dengan demikian dalam sistim yang baru kebijakan moneter lebih difokuskan pada pengendalian permintaan aggregat. Lebih jelasnya bahwa kebijakan moneter diarahkan untuk mengendalikan tekanan-tekanan permintaan (aggregate demand pressures) yang disebabkan oleh tingginya kesenjangan antara permintaan aggregat dengan output potensial (output gap). Hal ini mengingat besamya output gap tersebut menentukan tingkat laju inflasi dan laju pertumbuhan dalam ekonomi. Semakin tinggi output gap, laju pertumbuhan ekonomi dapat lebih tinggi akan tetapi akan dibarengi dengan laju inflasi yang lebih tinggi

17 Bahkan Amerika Serikat dan Jepang juga menempuh pendekatan yang pragmatis dan eklektik dalam manajemen moneternya. Baca Madigan (1994) untuk manajemen moneter di Amerika Serikat serta Sawamoto dan Ichikawa (1994) untuk Jepang. 
pula. Bank Indonesia harus menentukan seberapa jauh output gap tersebut akan diperkecil untuk menentukan imbangan antara sasaran laju inflasi dan laju pertumbuhan ekonomi yang dianggap paling "optimal".

Beberapa pendapat mengemukan perlunya Bank Indonesia lebih memfokuskan pada pencapaian satu sasaran yang diprioritaskan yaitu laju inflasi. Bank-bank sentral di berbagai negara seperti Kanada, Selandia Baru dan Australia juga telah mengarah pada pencapaian sasaran tunggal seperti ini. Bahkan Stanley Fischer (1994), Deputy Managing Director $\mathbb{I M F}$, juga menyatakan bahwa pengendalian inflasi perlu menjadi target utama kebijakan moneter bank sentral manapun di dunia. Hal ini didasarkan pada pertimbangan bahwa dalam jangka panjang kebijakan moneter hanya dapat berpengaruh terhadap laju inflasi, meskipun dalam jangka pendek mampu mempengaruhi pertumbuhan ekonomi (Guitan, 1994a). Selain itu, pencapaian sasaran tunggal tersebut tidak saja dapat menghilangkan trade-off antara sasaran-sasaran yang hendak dicapai akan tetapi juga dapat meningkatkan accountability dan credibility dari bank sentral yang bersangkutan. Pendapat demikian dapat saja diterapkan untuk Indonesia. Dalam konteks pemodelan ekonomi, pencapaian sasaran tunggal laju inflasi dapat direfleksikan sebagai pengendalian pemintaan aggregat untuk mengurangi output gap sekecil mungkin sesuai dengan sasaran laju inflasi yang ditetapkan. Dengan kata lain, Bank Indonesia tidak perlu lagi mempertanyakan imbangan antara laju inflasi dan laju pertumbuhan ekonomi yang dianggap "optimal" dalam melaksanakan kebijakan moneternya.

Bagaimana dengan sasaran kemantapan neraca pembayaran? Kebijakan moneter memang dapat mempengaruhi perkembangan neraca pembayaran melalui pengendalian permintaan aggregat. Akan tetapi nampaknya kebijakan moneter tidak lagi dapat difokuskan pada sasaran ini. Seperti telah dikemukakan, dalam sistim nilai tukar fleksibel kebijakan nilai tukar tidak lagi dapat diharapkan untuk meningkatkan kinerja ekspor. Selain itu, meskipun dapat mempengaruhi permintaan aggregat, kebijakan moneter akan menjadi sulit apabila diarahkan pula untuk mempengaruhi komposisi yang "optimal" antara permintaan domestik dan sektor eksternal dari permintaan aggregat tersebut.

\section{Sasaran Antara}

Tercapainya sasaran akhir laju inflasi dan laju pertumbuhan ekonomi tersebut akan sangat tergantung pada kemampuan Bank Indonesia dalam mempengaruhi permintaan aggregat baik konsumsi, investasi maupun transaksi berjalan. Untuk maksud ini Bank Indonesia dapat menggunakan model ekonomi makro yang telah ada (seperti MODBI) untuk memprakirakan seberapa besar permintaan aggregat yang dianggap aman sesuai dengan sasaran laju inflasi dan laju pertumbuhan ekonomi yang diinginkan. Sasaran tersebut diperlukan untuk dipergunakan sebagai acuan dalam memprakirakan besarnya demand pressures atau output gap yang dapat ditolerir dan perlu dikendalikan melalui kebijakan moneter yang dilakukan.

Langkah selanjutnya adalah merumuskan suatu indikator yang dapat dipergunakan sebagai sasaran antara dalam pengendalian permintaan aggregat tersebut. Dalam hubungan ini, Indikator Kondisi Moneter (IKM) yang ditempuh oleh Kanada, Selandia Baru dan Australia kiranya dapat digunakan sebagai acuan dalam penerapannya di Indonesia. IKM pada dasarnya mengukur pengaruh suku bunga dan nilai tukar terhadap aggregate demand pressures yang dicerminkan pada besarnya output gap sebagai berikut: 
$\operatorname{IKM}(\mathrm{v})=[\boldsymbol{\alpha}$ ( suku bunga (t) - suku bunga (base) ) + $\boldsymbol{\beta}$ ( REHR (t) - REFR (base) ) ] * 100

dimana IKM (v) mencerminkan aggregate demand pressures, $t$ menunjukkan periode sekarang, base adalah periode dasar, dan angka 100 untuk menunjukkan indeks. Suku bunga yang berpengaruh pada permintaan aggregat pada umumnya adalah suku bunga menengah-panjang. Untuk Indonesia, suku bunga deposito atau suku bunga kredit dapat dipergunakan sebagai proksi mengingat tidak adanya suku bunga menengah-panjang. REER adalah real effective exchange rate.

Parameter a dan b diperoleh melalui penaksiran fungsi permintaan aggregat dengan variabel suku bunga dan REFR sebagai variabel bebas. Dengan demikian suatu rasio IKM yang dicerminkan dengan $\mathrm{a} / \mathrm{b}$ menunjukkan seberapa kuatnya pengaruh suku bunga terhadap permintaan aggregat relatif terhadap pengaruh REER. Di Selandia Baru rasio IKM adalah $1 / 2$ sehingga menunjukkan bahwa 1\% pengaruh kenaikan suku bunga sama dengan 2\% apresiasi nilai tukar dalam mempengaruhi permintaan aggregat (Huxford dan Reddell, 1996). ${ }^{18}$ Dengan kata lain, agar permintaan aggregat tidak mengalami perubahan maka kenaikan suku bunga sebesar 1\% harus diimbangi dengan depresiasi nilai tukar sebesar 2\%. Semakin rendah rasio IKM berarti bahwa untuk mempengaruhi permintaan aggregat diperlukan fluktuasi nilai tukar yang lebih besar. Kanada, misalnya, mempunyai rasio IKM sebesar 1/3 sehingga kenaikan suku bunga 1을 yang diimbangi dengan depresiasi nilai tukar sebesar 3\% akan tidak banyak mempengaruhi permintaan aggregat (Freedman, 1994).19

Karena IKM dinyatakan dalam perubahan relatif terhadap periode dasar maka perkembangan IKM dari waktu ke waktu menunjukkan semakin besar tidaknya aggregat demand pressures. Kenaikan IKM menggambarkan semakin besarnya pengaruh suku bunga dan nilai tukar dalam mengurangi tekanan permintaan aggregat tersebut. Dengan kata lain, gerakan IKM menunjukkan ketat tidaknya stance dari kebijakan moneter yang ditem puh. Apabila Bank Indonesia ingin mengetatkan pengendalian moneter untuk mengantisipasi tekanan permintaan aggregat yang semakin besar maka IKM diupayakan untuk dapat ditingkatkan dari waktu ke waktu. ${ }^{20}$

Dalam kondisi perekonomian dan sektor keuangan kita yang semakin kompleks, Bank Indonesia hendaknya tidak mengandalkan satu indikator seperti IKM saja untuk mengarahkan manajemen moneter dalam mencapai sasaran akhir yang diinginkan. Berbagai variabel lain perlu dipergunakan sebagai variabel indikator ataupun variabel informasi dalam rangka lebih memahami perkembangan perekonomian dan arahnya ke depan. Dalam hubungan ini, pertumbuhan uang beredar (M1 dan M2) dan kredit dapat dipergunakan untuk menunjukkan tekanan permintaan aggregat di masa mendatang. ${ }^{21}$ Perkembangan

18 Untuk mendalami lebih lanjut manajemen moneter di Selandia Baru dengan menggunakan IKM, baca Huxford dan Reddell (1996) serta Economics Department Reserve Bank of New Zealand (1996)

19 Freedman (1994) memberikan penjelasan yang baik mengenai penggunaan IKM dalam manajemen moneter di Kanada.

20 IKM dapat dinyatakan secara nominal atau riil. Dalam jangka pendek perbedaan antara kedua pilihan ini tidak berarti mengingat actual inflation mendekati expected inflation. Akan tetapi dalam jangka panjang, untuk akurasi penggunaan IKM secara riil lebih baik sehingga pengaruh expected inflation dapat diperhitungkan.

21 Ingat bahwa pengaruh uang beredar dan kredit terhadap kegiatan ekonomi memerlukan waktu (lag). Dengan demikian, kenaikan pertumbuhan uang beredar dan kredit saat ini dapat mendorong kenaikan permintaan aggregat di masa yang akan datang. 
harga saham dan harga properti juga dapat digunakan sebagai indikator mengenai besarnya tekanan inflasi yang disebabkan oleh kenaikan harga asset (asset price inflation). Informasi lain seperti hasil survei kegiatan usaha, survei konsumsi dan survei-survei yang lain dapat pula digunakan Bank Indonesia dalam rangka semakin memahami gerakan ekonomi dimaksud. Berbagai variabel indikator tersebut dapat dikelompokkan sebagai prompt indicators, yaitu indikator yang dapat dipergunakan sebagai deteksi dini perkembangan ekonomi terkini, dan leading indicators, yaitu indikator yang dapat menunjukkan arah perkembangan ekonomi di masa mendatang. Kesemua ini pada dasarnya merupakan cerminan dari pendekatan eklektik dalam manajemen moneter di Indonesia sebagaimana dikemukakan di atas.

\section{Sasaran Operasional}

Pemilihan variabel yang dijadikan sebagai sasaran operasional dalam rangka mengarahkan gerakan IKM sebagai sasaran antara tersebut merupakan keputusan selanjutnya yang perlu dilakukan. Dalam hal ini, suku bunga PUAB, suku bunga SBI, atau tingkat diskonto SBPU merupakan tiga pilihan suku bunga jangka pendek yang dapat digunakan sebagai sasaran operasional. Pemilihannya didasarkan pada setidaknya dua pertimbangan. Pertama, seberapa cepat perubahan masing-masing suku bunga jangka pendek tersebut ditransmisikan ke perubahan suku bunga deposito atau kredit dan perubahan nilai tukar. Kedua, seberapa jauh suku bunga jangka pendek tersebut dapat dipengaruhi oleh instrumen kebijakan moneter yang dilakukan Bank Indonesia.

Ketiga jenis suku bunga jangka pendek tersebut mempunyai kelebihan sekaligus kekurangan masing-masing. Suku bunga SBI dan tingkat diskonto SBPU mempunyai kelebihan karena dapat dikendalikan oleh Bank Indonesia. Bahkan kedua suku bunga ini dapat sekaligus menjadi instrumen dan sasaran operasional kebijakan moneter. Perbedaannya terletak pada pandangan perbankan bahwa SBI sebagai alternatif investasi, sementara SBPU sebagai alternatif pendanaan. Karena itu tingkat diskonto SBPU sering diyakini lebih dekat hubungannya dengan suku bunga deposito dan kredit. Bagaimanapun juga penelitian yang lebih mendalam diperlukan untuk mengetahui kecepatan perubahan kedua suku bunga jangka pendek tersebut ditransmisikan ke suku bunga deposito atau kredit dan nilai tukar Rupiah.

Sementara itu, suku bunga PUAB mempunyai kelebihan karena lebih menggambarkan kondisi pasar uang sebagai salah satu alternatif pendanaan dan penanaman jangka pendek perbankan. Karena langsung mempengaruhi retum dan risk perbankan maka perubahan suku bunga ini diperkirakan lebih cepat ditransmisikan ke suku bunga deposito atau kredit. Selain itu, PUAB sering pula dipergunakan sebagai alternatif sumber pendanaan bagi transaksi di pasar valuta asing karena eratnya keterkaitan antara kedua pasar uang ini. Dengan demikian diperkirakan perubahan suku bunga PUAB lebih cepat pula ditransmisikan ke pergerakan nilai tukar Rupiah.

Penelitian yang pernah dilakukan di Bank Indonesia menunjukkan bahwa penentuan suku bunga di Indonesia melalui jalur yaitu: suku bunga SBI $\rightarrow$ suku bunga PUAB $\rightarrow$ suku bunga deposito $\rightarrow$ suku bunga kredit (Bond dan Kurniati, 1994). Apabila hasil penelitian ini dapat diterima, maka suku bunga PUAB dapat dipergunakan sebagai sasaran operasional sementara suku bunga SBI dan tingkat diskonto SBPU sebagai acuan dalam penggunaan instrumen kebijakan moneter. Tentunya penelitian dan pengkajian yang lebih seksama 
perlu dilakukan untuk menentukan suku bunga jangka pendek mana yang akan dipilih sebagai sasaran operasional.

\section{Instrumen Kebijakan}

Instrumen yang dipergunakan dalam manajemen moneter pada dasarnya sama dengan yang ada selama ini, yaitu: Operasi Pasar Terbuka (OPT), reserve requirement, fasilitas diskonto, dan moral suasion. Demikian pula titik berat pengelolaan moneter tetap pada penggunaan OPT sebagai instrumen utama. Perbedaannya adalah pada arah dari penggunaan instrumen manajemen moneter dimaksud. Kalau selama ini instrumen tersebut lebih diarahkan untuk mencapai sasaran uang primer (MO) pada tingkat tertentu, dalam sistim yang baru instrumen tersebut perlu lebih difokuskan pada pencapaian sasaran suku bunga jangka pendek yang diinginkan.

Perbedaan arah dari penggunaan instrumen tersebut tentu saja mempunyai implikasi pada implementasi manajemen moneter. Lelang SBI tidak lagi menitikberatkan pada kuantitas SBI yang diperlukan untuk mencapai sasaran uang primer yang ditetapkan dengan suku bunga SBI sebagai pertimbangan kecua. Dalam sistim yang baru lelang SBI lebih diarahkan untuk mencapai sasaran suku bunga SBI yang diinginkan dengan kuantitas SBI sebagai pertimbangan kedua. Suku bunga SBI yang ingin dicapai tersebut tentunya disesuaikan dengan tingkat atau kisaran suku bunga PUAB sebagai sasaran operasional atau, dalam hal suku bunga SBI sekaligus sebagai sasaran operasional, dengan tingkat IKM yang diinginkan sebagai sasaran antara.

\section{Kesimpulan}

Berbagai perubahan mendasar dalam perekonomian dan sektor keuangan telah menyebabkan paradigma lama manajemen moneter melalui transmisi uang beredar perlu dikaji ulang. Kita tidak bisa lagi terlalu mengandalkan pada pencapaian sasaran uang primer dan uang beredar (M1 dan M2) sebagai ukuran dari keberhasilan manajemen moneter. Hal ini mengingat telah terjadi perubahan mekanisme transmisi kebijakan moneter dalam mencapai sasaran akhir laju inflasi, laju pertumbuhan ekonomi, dan kemantapan neraca pembayaran. Transmisi kebijakan moneter melalui kuantitas seperti uang beredar dan kredit diyakini tidak sekuat dulu lagi. Mekanisme transmisi melalui harga seperti suku bunga dan nilai tukar diyakini lebih mendekati kenyataan di Indonesia dewasa ini dan di masa mendatang.

Berdasarkan pemikiran demikian, tulisan ini mengajukan proposisi mengenai paradigma baru manajemen moneter melalui transmisi suku bunga dan nilai tukar yang kiranya dapat diterapkan di Indonesia. Sasaran akhir dari kebijakan moneter hendaknya lebih dititikberatkan pada pengendalian laju inflasi. Sebagai sasaran antara, Indikator Kondisi Moneter (IKM) yang merupakan pengaruh gabungan suku bunga dan nilai tukar terhadap permintaan agregat dapat dipergunakan, disamping berbagai variabel indikator seperti pertumbuhan uang beredar, kredit, harga saham, harga aset, dan leading indicators . Operasi Pasar Terbuka hendaknya tetap dipergunakan sebagai instrumen utama kebijakan moneter dengan mengarahkan lelang SBI pada penentuan suku bunga SBI sesuai mekanisme pasar untuk mempengaruhi suku bunga PUAB sebagai sasaran operasional. 


\section{DAFTAR PUSTAKA}

Agung, Juda, "Financial Deregulation and Substitutability of Monetary Assets in Indonesia", Department of Economics, University of Bimingham, 1995.

Bernanke, B., and Blinder, A., "The Federal Funds Rate and the Channels of Monetary Transmission", NBER Working Paper No.3487., 1992.

Blinder, A., "On the Conceptual Basis of Monetary Policy", Remarks for the Senior Excecutives Conference of the Mortgage Bankers Association, New York, 1996.

Boediono, "Melihat Kembali Target Moneter Kita : M0, M1, atau M2?", Catatan Direktur Bidang Moneter, Bank Indonesia, Oktober 1994.

"Merenungkan Kembali Mekanisme Transmisi Moneter di Indonesia", Catatan Direktur Bidang Moneter, Bank Indonesia, Juni 1996.

"Mekanisme Transmisi Kebijakan Moneter", Bahan Kuliah Khusus Sespibi Angkatan XXI, September 1996.

Bond, Timothy J., et al., "Money, Interest Rates, and Inflation", URES Discussion Paper, Bank Indonesia, Juni 1994.

dan Yati Kurniati, "The Determination of Interest rates in Indonesia", URES Discussion Paper, Bank Indonesia, Juli 1994.

et al., "Monetary Management with an Exchange Rate Target", URES Discussion Paper, Bank Indonesia, Agustus 1995.

Djiwandono, Soedradjad J., "Ekonomi Makro dalam Dinamisme Perekonomian Dunia: Tantangan bagi Pendekatan dan Kebijaksanaan Makro", Pidato Upacara Pengukuhan Jabatan Guru Besar Tetap dalam Ilmu Ekonomi pada Universitas Indonesia, Juli 1994.

, "Masalah dan Kebijakan Moneter-Perbankan Indonesia: Perannya dalam Pembangunan dan Perkembangan Dewasa Ini", Ceramah Gubernur Bank Indonesia pada Kursus Singkat Angkatan VI Lemhannas, April 1996.

Sambutan Gubernur Bank Indonesia pada Upacara Pembukaan Sespibi Angkatan XXI, September 1996.

Edey, Malcolm, dan Romalis, John, "Issues in Modelling Monetary Policy", Reserve Bank of Australia, May 1996.

Fischer, Stanley, "Central Banking : the Challenges Ahead", the 25th Anniversary Sysmposium of the Monetary Authority of Singapore", May 1996.

Fraser, Bernie, "The Art of Monetary Policy", Talk by Governor of the Reserve Bank of Australia in 23rd Conference of Economists, September 1994.

Fuhrer, J.C., and Moore, G.R., "Monetary Policy Trade-offs and the Correlation Between Nominal Interest Rates and Real Output", American Economic Review, 1995. 
Grenville, S.A., "An Overview of Current Issues in Monetary Policy", Memorandum to Governor and Managing Director, Bank Indonesia, November 1993.

Grenville, S.A., dan Stebbing, P.W., "Monetary Management the Australian Experience", International Conference on Monetary Management, Denpasar-Bali, 1994.

Hadad, Muliaman D., "Bank Behaviour in a Changing Regulatory Environtment : Study of Indonesia 1983-1993", a Ph.D. Thesis Monash University, April 1996.

Haldane, A.G., "Rules, Discretion and the UK's NewMonetary Framework", paper on Bank of England's Inflation Targets Conference, Maret 1995.

Harinowo, C., dan Belchere, W., "Monetary and Exchange Rate Management with International Capital Mobility", Pacific Basin Central Bank Conference, Hong Kong, October 1994.

Harris, L., "Monetary Theory", McGraw-Hill Book Company, 1981.

Iljas, Achjar, "Suatu Tinjauan Mengenai Penggunaan Nilai Tukar Sebagai Nominal Anchor dalam Pengendalian Inflasi di Indonesia", Makalah Sespibi Angkatan XVII, 1992.

Moore, Basil J., "Horizontalists and Verticalists : the Macroeconomics of Credit Money", Cambridge University Press, 1988.

Poole, William, "Monetary Policy Implications of Recent Changes in the Financial System in the United States and Europe", the Sixth International Conference organized by the Institute for Monetary and Economic Studies, Bank of Japan, October 1993.

Sarwono, Hartadi A., Alamsyah, Halim, "Sasaran Pengendalian Uang Beredar : Two Step Cointegration Approach", URES Discussion Paper, Bank Indonesia, 1993.

Bank for International Settlements (BIS), Financial Structure and the Monetary Policy Transmission Mechanism, Basle, March 1995.

gust 1994 et. al., "Monetary Targets", URES Discussion Paper, Bank Indonesia, Au-

Dornbusch, Rudiger, "Expectations and Exchange Rate Dynamics, Joumal of Political Economy, Nomor 84, 1976.

, Open Economy Macroeconomics, Basic Books Inc., New York, 1980.

Economics Department, Reseve Bank of New Zealand, "Summary Indicators of Monetary Condition", Reserve bank Bulletin, Vol. 59 No. 4, 1996.

Edwards, Sebastian, "Exchange Rate Misalignment in Developing Countries", dalam IMF Institute, Approaches to Exchange Rate Policies, Washington, D.C., 1994.

Flood, Robert P. dan Mussa, Michael, "Issues Concerning Nominal Anchors for Monetary Policy", dalam Thomas J.T. Balino dan Carlo Cottarelli, Frameworks for Monetary Stability", IMF, Washington, 1994. 
Freedman, C., "The Use of Indicators and of the Monetary Conditions Index in Canada", dalam Thomas J.T. Balino dan Carlo Cottarelli, Frameworks for Monetary Stability', IMF, Washington, 1994.

Friedman, Benjamin M., "Targets, Instruments, and Indicators of Monetary Policy", Journal of Monetary Economics, Oktober 1975.

Guitan, Manuel, "Rules or Discretion in Monetary Policy: National and International Perspectives", dalam Thomas J.T. Balino dan Carlo Cottarelli, Frameworks for Monetary Stability", IMF, Washington, 1994a.

"The Choice of Exchange Rate Regime", dalam IMF Institute, Approaches to Exchange Rate Policies, Washington, D.C., 1994b.

Huxford, Julie dan Reddell, Michael, "Implementing Monetary Policy in New Zealand", Reserve bank Bulletin, Vol. 59 No. 4, 1996.

Madigan, Brian F., "The Design of U.S. Monetary Policy: Targets, Indicators, and Information Variables", dalam Thomas J.T. Balino dan Carlo Cottarelli (editors), Frameworks for Mbnetary Stability, IMF, Washington, 1994.

Mishkin, Frederic S., Symposium on the Monetary Transmission Mechanism, Joumal of Economic Perspectives, Vol. 9, No. 4, Fall, 1995.

Sawamoto, Kuniho dan Ichikawa, Nobuyuki, "Implementation of Monetary Policy in Japan" dalam Thomas J.T. Balino dan Carlo Cottarelli (editors), Frameworks for Monetary Stability, IMF, Washington, 1994. 